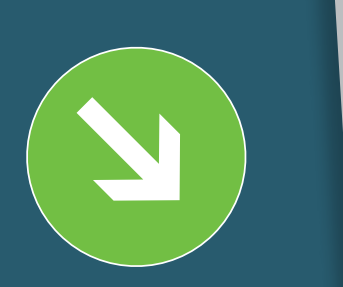

Ключевые слова: робототехника, мехатроника, биопринтинг, тканевая инженерия, регенеративная медицина

\section{РОБОТИЧЕСКИЕ ТЕХНОЛОГИИ} В МЕДИЦИНЕ И БИОПРИНТИНГЕ

\section{Юрий ПОДУРАЕВ}

\begin{abstract}
Рассмотрены существующие примеры применения роботических и мехатронных технологий в медицине. Дан обзор технологии биопринтинга, как наиболее современного и перспективного направления регенеративной медицины. Приведены примеры проектов по роботизации в области стоматологии и челюстно-лицевой хирургии.
\end{abstract}

Одними из ключевых направлений, которые обеспечат основу инновационного развития внутреннего рынка продуктов и услуг, а также устойчивого положения России на внешнем рынке, согласно стратегии научно-технического развития Российской Федерации, утвержденной Указом Президента Российской Федерации от 1 декабря 2016 года № 642, являются:

$\rightarrow$ переход к передовым цифровым, интеллектуальным производственным технологиям и роботизированным системам, новым материалам и способам конструирования;

$\rightarrow$ переход к персонализированной медицине, высокотехнологичному здравоохранению и технологиям сбережения здоровья населения [1].

Осуществление развития по данным направлениям невозможно без глубокой интеграции роботических и мехатронных технологий во все сферы медицинской деятельности от диагностики и консультирования пациентов до робот-ассистированной хирургии.

Главной целью сотрудничества робототехники и медицины является повышение эффективности лечения и уменьшение рисков нанесения вреда здоровью человека при выполнении обследования или операции. Для достижения поставленной цели при создании медицинских робототехническихустройств необходимо использовать мехатронный подход, суть которого состоит в синергетическом объединении при конструировании элементов различной физической природы $[2,3]$.
Исторически первая роботизированная хирургическая система была разработана для нейрохирургии в 1985 году. Основу системы составлял манипулятор PUMA 650 со специальной оснасткой. Планирование движений манипулятора при операции осуществлялось по данным томографии. В настоящее время данная система не используется из-за повышенного риска для пациента во время операции [4].

Логическим развитием роботизированной хирургии стали системы RoboDoc (рис. 1 a), Aesop (рис. 1 б) и ZEUS (рис. 1 в). Данные системы не являются полностью автономными, главная их задача - ассистирование врачам при проведении различных хирургических вмешательств. Вершиной развития робот-ассистированной хирургии на сегодняшний день по праву считается комплекс Da Vinci, разработанный компанией Intuitive Surgical.

Основные преимущества, которые дает применение роботических технологий в хирургии на сегодняшний день таковы:

$\rightarrow$ расширение естественных манипулятивных и сенсорных возможностей врача при диагностике или выполнении операции;

$\rightarrow$ обеспечение стабильного качества выполнения операций и обследований за счет исключения большинства случайных факторов, воздействующих на врача (тремор, непроизвольные движения рук и т.д.);

$\rightarrow$ повышение доступности высококвалифицированной медицинской помощи за счет проведения удаленных операций (телехирургия), обследований и др. 

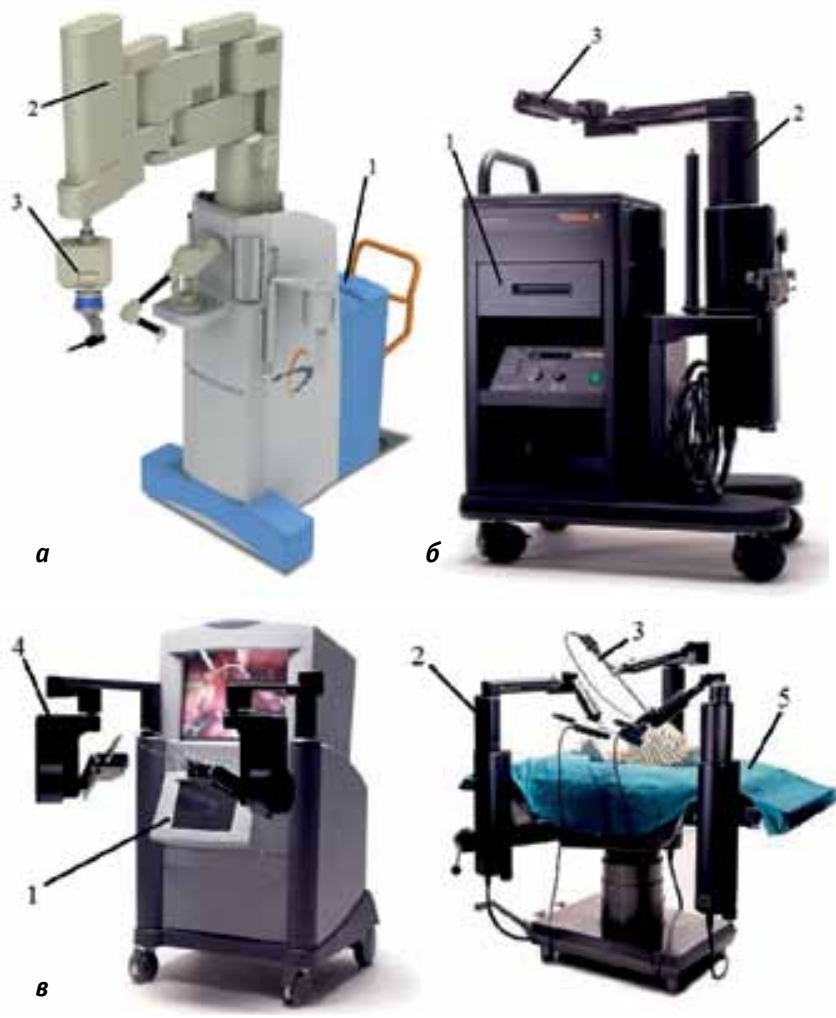

Puc. 1. Роботизированные хирургические комплексы: $a$-RoboDoc; 6 - Aesop; в - ZEUS (1 - рабочеe место хирурга; 2 - манипулятор; 3 - рабочий инструмент; 4 - джойстики; 5 - стол пациента)

Перспективным развитием роботизированной хирургии является трансоральная хирургия, хирургия головы и шеи и гинекологическая хирургия. Стоит отметить, что к 2014 году появилось более 6000 публикаций, посвященных роботизированной хирургии, что свидетельствует о высоком интересе научного сообщества к данному направлению [4].

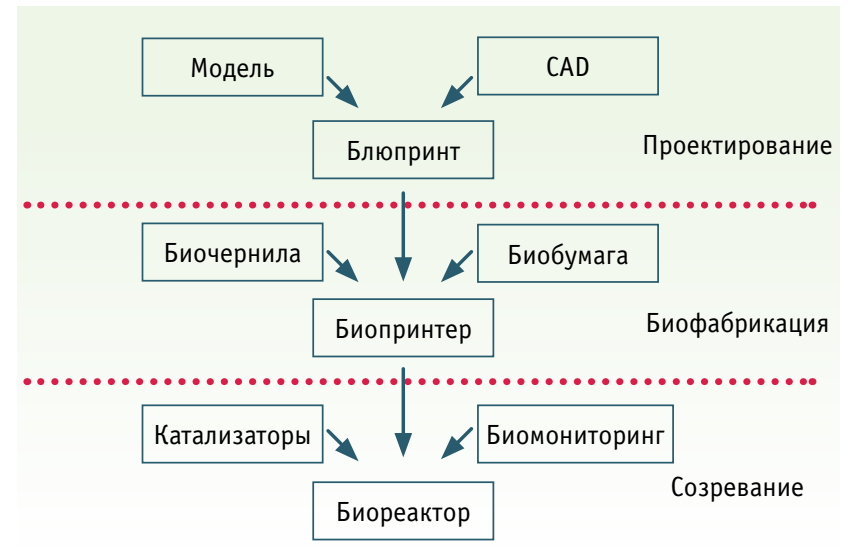

Puc. 2. Основные этапы биопринтинга
Основу технологии биопринтинга составляет 3D-печать, то есть послойное создание физического объекта на базе виртуальной трехмерной модели. В качестве физического объекта в биопринтинге выступают живые органы или отдельные их элементы, которые впоследствии пересаживаются пациенту [5, 6].

Основные концептуальные этапы при печати живых органов по технологии биопринтинга приведены на рис. 2 [7]. На этапе проектирования происходит создание так называемого блюпринта, то есть «чертежа» будущего органа с указанием особенностей его внутреннего строения. После создания блюпринта происходит его биофабрикация (печать). При этом используются биочернила, представляющие собой клеточные агрегаты, и биобумага - гидрогель, который будет служить основой каркаса будущего органа. Заключительным этапом биопринтинга является созревание напечатанного органа. При помощи специальных веществ в биореакторе происходит трансформация клеточных конгломератов в тканевые структуры, пригодные для пересадки и обладающие требуемыми свойствами.

Применение роботических и мехатронных технологий в биопринтинге позволяет не только улучшить качество печати и разрешающую способность биопринтера, что дает возможность печатать органы с более сложной структурой, но и позволяет перейти к качественно новому этапу развития регенеративной медицины, то есть биопечати in vivo и in situ.

На сегодняшний день существуют концептуальные проекты лазерной биопечати in situ в стоматологии (рис. 3 a) и in vivo в хирургии (рис. 3 б) [8]. Ключевой особенностью данных проектов является использование роботов-манипуляторов для перемещения экструдера при печати тканей.

Как следует из представленного выше обзора, применение роботических технологий в медицине обеспечивает достижение качественно новых результатов в лечении и диагностике многих заболеваний. На сегодняшнийдень в МГТУ «СТАНКИН» совместно с МГМСУ им. А.И. Евдокимова реализуются два проекта по роботизации в стоматологии и челюстно-лицевой хирургии.

$\rightarrow$ Разработка экспериментального обоснования модели роботизированного мультифункционального хирургического комплекса с лазерным рабочим органом. В рамках выполнения проекта был разработан стенд роботизированного хирургического комплекса, включающий в себя следующие подсистемы: манипуляционный робот-ассистент, мануальный тренажерный комплекс, фантом головы пациента и рабочее место хирурга. Результаты этой работы 

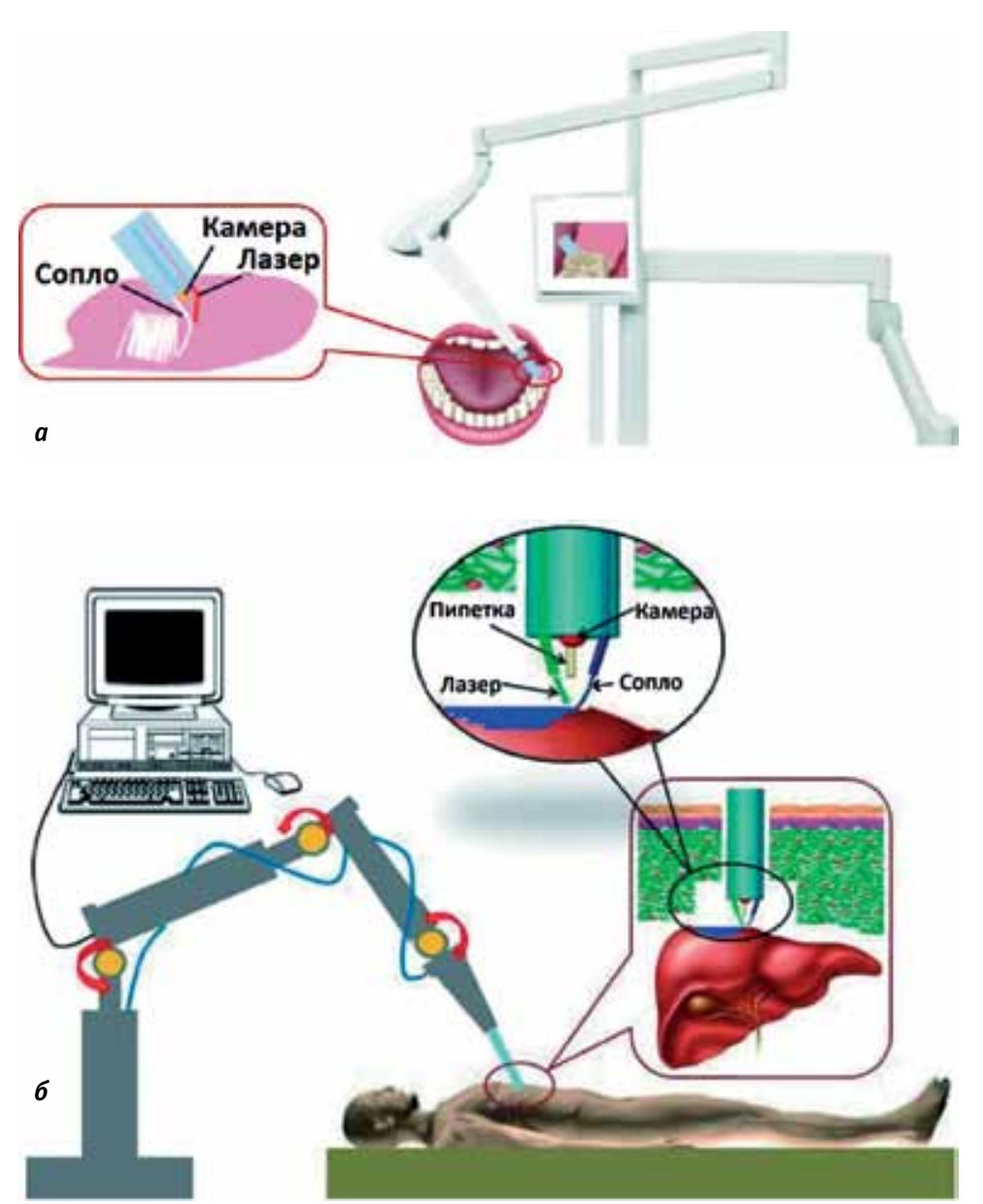

Puc. 3. Применение роботов для биопечати: $a$ - печать in situ; $\sigma$ - печать in vivo

были продемонстрированы в эфире программы «Здоровье» с Еленой Малышевой, выходящей на Первом канале. На данный момент для правовой защиты интеллектуальных результатов разработки в «Федеральный институт промышленной собственности» поданы две заявки на патент и полезную модель.

$\rightarrow$ Разработка методов построения и компьютерного моделирования пространственных 3D-зон для безопасных движений медицинских инструментов в робото-ассистированной хирургической системе с целью создания перспективных робото-ассистированных хирургических систем, обладающих свойствами и характеристиками, которые принципиально превышают возможности естественных систем человекаоператора (механических, сенсорных, интеллектуальных) при мануальной хирургии за счет новых функциональных возможностей медицинских роботов.

Результаты исследований в этом направлении предполагается использовать при обучении и атте- стации врачей различных направлений хирургии, а также в учебных дисциплинах, связанных с проектированием и применением медицинских робототехнических систем.

Работа выполнена при поддержке Минобрнауки России в рамках выполнения государственного задания (9.3408.2017/ПЧ).

\section{ЛИТЕРАТУРА}

1. Указ Президента Российской Федерации от 1 декабря 2016 г. № 642 «О Стратегии научно-технологического развития Российской Федерации».

2. Подураев Ю.В. Мехатроника: основы, методы, применение: учебное пособие для студентов вузов. - М.: Машиностроение, 2006. 256 с.

3. Подураев Ю.В. Актуальные проблемы мехатроники // Мехатроника, автоматизация управление. 2007. № 4. С. 50-53.

4. Колонтарев К.Б., Пушкарь Д.Ю., Говоров А.В., Шептунов С.А. История развития роботических технологий в медицине // Известия ВУЗов. Поволжский регион. Медицинские науки. 2014. № 4 (32). C. $125-140$.

5. Mironov V., Boland T., Trusk T., Forgacs G., Markwald R. Organ printing: computer-aided jet-based 3D tissue engineering. Trends Biotechnol. 2003. № 21. P. 157-161.

6. Mironov V., Kasyanov V., Markwald R. Organ printing: from bioprinter to organ biofabrication line. Current Opinion in Biotechnology. 2011. № 22. P. 667-673.

7. Миронов В.А. Технология трехмерной биопечати [Электронный ресурc] URL:http://umedp.ru/news/ vladimir_aleksandrovich_mironov_tekhnologiya trekhmernoy_biopechati.html. Дата доступа 30.03.2017.

8. Manyi Wang, Jiankang He, Yaxiong Liu, Meng Li, Dichen Li1, Zhongmin Jin The trend towards in vivo bioprinting. International Journal of Bioprinting. 2015. № 1. Vol. 1. P. 15-26.

\section{ПОДУРАЕВ Юрий Викторович -}

доктор технических наук, заведующий кафедрой робототехники и мехатроники МГТУ «СТАНКИН» 